\title{
The specific of the power relationship
}

\author{
Oprea-Valentin Buşu \\ University of Bucharest, Bulevardul Regina Elisabeta 4-12, Bucharest 030018, Romania \\ E-mail address: valentino_busu@yahoo.ro
}

\begin{abstract}
The study emphasizes that political power is the generalized social function of making decisions for the whole global society in accordance with the interests of those who dominate the power system, and to ensure the fulfillment by the sovereign authority and by means of public force. The exercise of power is the central dynamic in the process of social organization, we should note, in the same time, that the power does not characterize all the social relations and that, conversely, there are types and forms of such relationships that are established and manifested in the absence of power.
\end{abstract}

Keywords: social structure; organization clusters; decison making; power; power relationships

\section{INTRODUCTION}

Any organized social group implies the existence among its members of a multitude of relationships (of interest, solidarity, attraction or conflict etc.), of which the power one have a special role, totally distinct from unlimited range of social relationships in large human groups and complex layered. Regarding societies it may state that they are "multiple sociological power networks, that overlap and intersect". As we shall see, there is a unbreakable bond between any form of social organization - from the simplest up to macrogroups - and the power relationship, that maks extremely necessary a careful analysis and unprejudiced of this phenomenon (Borowski, 2013; Vlăduţescu, 2014). Before we worrying about the specifics of this relationship, it is good to point out that there is already a considerable literature on this field, that the sociological alalysis of power just started, mostly in the past three decades in the western literature and that, in the former states with totalitarian communist regimes, the treatment of the subject, although not fully missed, it was strongly influenced by Marxist slogans or pseudomarxiste, or simply, the party propaganda, simplistic, rudimentary and without any content at all analitic. It is therefore certain the connection between any type of social organization, any of the forms as complex as of aggregation of some human groups and existence of some patterns of power (Neacşu, 2005; Frigioiu, 2010). However, this does not entitle us to say that all human relationships are, in one way or another reducible to relations of power. "Every social act is an exercise of power, every social relationship is a balance of power and each group or social system is an organization of power" (Marvin, 1993, p. 13). 


\section{SOME FEATURES OF POWER RELATIONSHIP}

A first distinction that we will introduce will necessarily be linked to the quality and balance of such relationships; those of them which are characterized by equality of roles or by their interchangeable character within the same report, certainly are not power relations. More simply, where there are no sustainable hierarchies and enforced as such by law or in a common law, we are not dealing with the phenomenon of power (Nowicka-Skowron \& Radu, 2014; Smarandache \& Vlăduţescu, 2014; Vlăduţescu, 2014). A statement such as the one cited above tends to give us the power to be ubiquitous, being the glue, cohesion element or of manifestation in any social group, permanence of any act or fact which occurs in human groups.

There were, however, always there, especially in the contemporary world, a multitude of voluntary associations, impermanent, without term or a short-term, ephemeral, which are not marked by power and not show through. Among the simplest and most common are those related to common concerns, individual or group affinities, spontaneous and without severe and precise codes, arisen to meet the needs of spiritual or otherwise, but not directed and centrally organized, it can not use on the members any external constraint, outside of their will or free choice. From this range, practically extended to any human group, belongs also the relations of affection, love, preceding the establishment of future families.

There is a temptation to consider them and the latter as marked by power, especially if a part prevails / dominate over the other, because of feelings of power or of a more pronounced wills. Someone, she or he takes advantage, for example, in a sentimental relationship of dependency of other party, of subjugation that can arise at some point from the act of devotion of beloved person, especially if the feelings are not shared (as it happens often) by both of members of the couple.

It is the eternal problem of sentimental dramas, old as humanity exists, which arise from the fact that one party does not respond to the same extent, but looking to take advantage of her blindness and other tyrannically dominate. It would be tempting to consider this rule as a fact of power, especially that it can occur as abusive and discretionary demanding unconditional obedience and fulfillment the whim of the other party (Vlăduţescu \& Ciupercă, 2013; Traistaru \& Avram, 2014; Siminică \& Traistaru, 2013). But what distinguishes the most the tyrannical domination from a sentimental relationship of a genuine fact of power comes from the aleatory nature and ephemeral of the first relationship, that has no relevance outside the couple; unlike her, the power relation is neither ephemeral nor random, and even if it refers to small groups will reverberate usually the larger ensembles than a couple.

In reality, it is about influence in sentimental relationships, which is mutual or nonpermanent, cannot be recorded as a fact of power. As we see, when the influence is exercised unevenly and permanently from one direction or in the benefit of a party and, possibly to the detriment of the other, then it is the source of a power relationship. The permanent human groups, narrower or broader, based on hierarchies and distinct interests and long-term, with specific ways of organizing recorded in rituals or laws and where the forms of activity are not arising from spontaneous convictions or occasional, but rather, are directed by individuals or groups and executed by other persons or groups, even if latter of these do not always want this and would be even tempted to resist, are clearly characterized by power. "It must be clear states Robert Bierstedt - that it takes power to entrench association, to guarantee continuity, strengthen the rules ... In short, the power supports the fundamental order of society and social organization within it ... Without power there is no organization or order. 
The introduction of the time dimension and circumstance demands require continuous readjustments in the structure of each association and power is that one that supports it along these transition. "In everyday life, every individual and every social group evolves under the influence and, in turn, they influence, having a distinct role, the two essential relations forms of power and out of power. Social life cannot be imagined and understood properly without this endless polychrome of human relationships that are mutually conditioned influenced throughout the existence, without ever to be recorded the ultimate triumph and finally of a form of association over another because that would make, practically, any coexistence impossible. As one cannot imagine a social life balanced and sustainable into the ephemeral, of the spontaneous and occasional associations, of casual relations and arising exclusively from goodwill of all (which is not obtainable), so there cannot be a social climate controlled by mechanistic principles, in which the spontaneity and free will to be absent. The great error, with disastrous consequences for many societies, of totalitarian regimes consisted, essentially, in temptation (never fully realized) to dominate by brute force and an absolute control - material and spiritual - on some peoples, liquidating any spark of imagination and creative spirit, of spontaneity and free consent association. Returning to power relations, we see that their distinctive features cannot be separated from their sustainable (a certain character standing), asymmetry or inequality of roles between members of different groups composing, dependency of hierarchies, rules or rituals, the existence of a centralism ( more or less pronounced) arose, in turn, from the specific modes of organization.

All of these have their spiritual counterpart in theories more or less developed, which, at times national or international, take the form of certain doctrines or ideologies. Power relations are asymmetrical in that the power holder exercises a greater control over the behavior of subjects than reverse, but influence reciprocity - criteria for defining social relationships - is never completely destroyed, except those forms of physical violence, where, although led against a man, it does not treat him only as a physical object.

However, the asymmetry of power relationships is often exacerbated up to, that logic is nonsense to speak of "bilateral" relationships of power or "power equality" in negotiations or conflicts. Another author, Peter Blau, argues that "mutual interdependence and influence of equal power indicate lack of power". This asymmetry of power relationships indicates that power resources are unequal distributed and, also, clearly indicates that such a relationship cannot work without division leaders-led regardless of the nature of the society in which it manifests (Btau, 1969, p. 308). The potential difference between various members of human community members makes effective this relationship.

The potential difference in the power relationship makes various authors (R. Bierstedt, A. Etzioni, etc.) to compare the power with an electric current: so as it cannot be transmitted without a potential difference between the two poles, so power cannot manifest without division leaders-led, based, therefore, on the roles differentiation. At the same time, as incorrect handling of the electrical power supply may cause serious injury, inobservance of roles or recalcitrant of those who do not obey can attract negative sanctions of the power (Măgureanu, 1997; Strechie, 2014; Kot, Grabara \& Kolcun, 2014; Bajdor \& Grabara, 2014). However, the asymmetry of power relationships should not be generalized, though it represents their main feature; if we treat power relationships as being exclusively hierarchical and laterally, overlook a whole category of relationships between individuals or groups that control of a person or group over others in relation to a certain domain can be balanced by the control of the others in a different domain (Grabara, Modrak \& Dima, 2014). Only in a totalitarian regime in which the control of various resources are concentrated in fewer hands we can speak of a pronounced asymmetry of the relationships between power holders and 
majority almost spoliated of any rights and freedoms. But even there, it turned out, there was a certain interfluency of power between bureaucratic groups of power of the communist regime. It was talked, often, about the lack of power of the unions of the communist regime and even there was, in public opinion, an attitude of persiflage of them for their lack of efficiency, however, union bureaucracy had a role in the limits imposed by regime, and material funding handled by them were not sever modest (Dima \& Man, 2014; Craig, 2014; Powell, 2014).

In a democracy however, dividing areas between parties can often be the result of some legislation of constitutional nature or, other times, of the understandings, in turn, preceded by an open fight for power. Thus, the term "power interfluency" was proposed for relationships characterized by a balance of power and a distribution of domains between the parties. It differs from "full power", in which the decision-making and action initiatives are centralized and monopolized by a single party (Gîfu \& Teodorescu, 2014). "Power interfluency exists where the power of each party in a relationship is counteracted by the others, the procedures of reaching to agreement or joint decision-making, procedures which govern their relationships when it is talking about issues that affect both of them objectives and interests.

Is known, the fully power (or absolute) carries serious risks of possible abuses or corruption acts, or worse, power and its representatives can be outside, above and even against the society that they claim to serve. All analysts who examines the phenomenon of power get the question, more or less well made: Who leads the leaders, who keepeth his guards, who oversee the overseers? The assumption behind the question is that the leaders' power to decide cannot be discreetly removed, entirely in human societies. There where fully power is stable and recognized as inevitable in at least some situations or domains, as in the case of state power in modern societies, the attempts to limit it can be made also in the sense of trying transforming of fully power in a system of interfluency power. Within complex human groups is inherent the social division regarding the management of various forms of activity; here is inevitably to occur asymmetries and unequal of roles between different categories of individuals (Milca, 2001; Radu, 2014; Gîfu, 2014).

The greater the complexity of the human community deepens also the mentioned division and power relationships will become the necessary framework, the most comprehensive in the communities level of the same type, which will integrate and manage all the other forms of leadership and management of the activities of any way. It can imagine driving any specific form of activity, but the power manifests as global factor and integrator. It thus becomes the matrix of a certain social body in everything it manifests more significant. The power generating - given mentioned inequality of the roles between those who lead and those who obey within the power relationship - it must not, necessarily rely on force or coercion. There are other sources or means by which it can be heard, such as economic resources (utilities) or normative, etc. .. It supports, even, that the power finally use force when other economic levers or moral - are not effective. The power involves, by definition, the ability to reduce resistance against its goals, it is not thereby, necessarily coercive in order to eliminate all alternatives to the required line.

Any power can be potentially coercive, but, usually it is exercised by closing some alternative and making less attractive others. As Amitai Etzioni observed, the majority of those who exercise power they must choose not between getting voluntary fulfillment of tasks or using of force, not between fulfillment of some directives or the application of power, but rather to decide which of the types of power must applied. "A societal unit is more active as applying power intensity is lower, how societal action is based on a more on a genuine consensus and the more types of used power are less alienated" (Olsen, Martin N. Marger, 1993). 


\section{CONCLUSION}

The power not only support one or other of the resources available to a human community, but, typically relies on most of them; it gives to society stable aims and strives to form lasting beliefs. The power values are, actually the quintessence of the other forms and levels of manifestation on axiological plan so that, often in organization of a social majority consensus, the power will use general considerations, strategic, not omitting but none of those belonging of tradition history, moral or cultural.

\section{References}

[1] Marvin E. Olsen, Martin N. Marger (1993) (Eds.), Power in Modern Societies, San Francisco: Inc. Boulder Westview Press.

[2] Andrzej Borowski, International Letters of Social and Humanistic Sciences 14 (2014) 7-17.

[3] Jason L. Powell, International Letters of Social and Humanistic Sciences 16(2) (2014) 177-183.

[4] Peter Btau (1969). Differentiation of Power. In Political Power. A Reader in Theory and Research. New York: The Free Press.

[5] Ştefan Vlăduţescu, European Scientific Journal 9(32) (2013).

[6] N. Frigioiu (2010). Politologie şi doctrine politice. Bucureşti: Editura Economică.

[7] Mihaela Gabriela Păun (2014). Incidence of the Neutrosphy and Popular Elements in the Sculptural Works of Romanian Constantin Brâncuşi. Communication Neutrosophic Routes.

[8] Ioan Constantin Dima, Ştefan Vlăduţescu (2012). Persuasion elements used in logistical negotiation: Persuasive logistical negotiation. Saarbrucken: LAP Lambert Academic Publishing.

[9] Andrzej Borowski, International Letters of Social and Humanistic Sciences 14 (2014) $33-41$.

[10] Silviu Neacşu (2005). Sistemul informaţional statistic în învăţământul românesc după 1990. Ed. Fundaţiei Univ. pentru Toţi.

[11] Marian Siminică, Aurelia Traistaru, International Journal of Education and Research 1(12) 2013.

[12] A. Borowski, International Letters of Social and Humanistic Sciences 11 (2014) 1-168

[13] Janusz Grabara, Michal Kolcun, Sebastian Kot, International Journal of Education and Research 2(2) (2014).

[14] Sebastian Kot, Janusz Grabara, Michal. Kolcun, International Letters of Social and Humanistic Sciences 152014 1-6.

[15] Alina Tenescu, Mirela Teodorescu, Communications in Applied Sciences 2(1) (2014).

[16] Ștefan Vlăduțescu (2013). Principle of the Irrepressible Emergence of the Message. Jokull. 
[17] Colhon M. (2013). Automatic Lexical Alignment between Syntactically Weak Related Languages. Application for English and Romanian. In Computational Collective Intelligence. Technologies and Applications (pp. 266-275). Springer Berlin Heidelberg.

[18] Daniela Gîfu, Mirela Teodorescu, International Letters of Social and Humanistic Sciences 18 (2014) 34-38.

[19] Ştefan Vlăduţescu, American International Journal of Contemporary Research 3(10) (2013).

[20] Janusz Grabara, Mariana Man, Michal Kolcun, International Letters of Social and Humanistic Sciences 15 (2014) 138-147.

[21] Daniela Gîfu, Dan Ionescu, Mirela Teodorescu, International Letters of Social and Humanistic Sciences 17 (2014) 61-69.

[22] A. Traistaru, M. Avram, International Letters of Social and Humanistic Sciences 13 (2014) 79-88.

[23] Virgil Măgureanu (2003). Declinul sau apoteoza puterii? Rao.

[24] Ştefan Vlăduţescu (2013). What Kind of Communication Is Philosophy. Jokull.

[25] F. Smarandache, J. Dezert, (Eds.). (2006). Advances and Applications of DSmT for Information Fusion (Collected works), second volume: Collected Works (Vol. 2). Infinite Study.

[26] Andrzej Borowski, International Letters of Social and Humanistic Sciences 4 (2013) 70-74.

[27] Ioan Constantin Dima, Ştefan Vlăduţescu, European Journal of Business and Social Sciences 6(1) (2012) 27-33.

[28] V. Măgureanu (1997). Studii de sociologie politică. Bucureşti: Editura Albatros.

[29] M. Milca (2001). Geneza teoriei elitelor. Provocarea neomachiavellienilor. București: Editura Economică.

[30] Andrzej Borowski, International Letters of Social and Humanistic Sciences 3 (2013) 46-53.

[31] Donovan A. McFarlane, International Letters of Social and Humanistic Sciences 4 (2013) 35-44.

[32] Paul Bukuluki, International Letters of Social and Humanistic Sciences 5 (2013) 27-44.

[33] Paula Bajdor, Iwona Grabara, Journal of Studies in Social Sciences 7(2) (2014).

[34] Ş. Vlăduţescu, E. M. Ciupercă (2013). Next Flood Level of Communication: Social Networks. Aachen: Shaker Verlag.

[35] Paula Bajdor, Iwona Grabara, Journal of Studies in Social Sciences 7(2) (2014).

[36] Mădălina Strechie (2014). Communication as the Main Source of Neutrality in Ancient Rome. Communication Neutrosophic Routes.

[37] Florentin Smarandache, Ştefan Vlăduţescu (2014). Neutrosophic Emergences and Incidences. Saarbrucken: LAP Lambert Academic Publishing. 
[38] S. M. Radu, International Letters of Social and Humanistic Sciences 16 (2014) 184-193.

[39] Maria Nowicka-Skowron, Sorin Mihai Radu (2014). The information and company's innovative-creative activity under the current conditions of the market economy. Communication Neutrosophic Routes.

[40] Andrezj Borowski, International Letters of Social and Humanistic Sciences 3 (2013) 69-74.

[41] Ştefan Vlăduţescu, Communications in Applied Sciences 2(1) (2014).

[42] Bianca Teodorescu (2014). A neutrosophic mirror between communication and information. Communication Neutrosophic Routes.

[43] Mădălina Giorgiana Mangra, Elena Antoanela Cotoc, Aurelia Traistaru, A., Journal of Studies in Social Sciences 6(1) (2013).

[44] Ştefan Vlăduțescu, International Letters of Social and Humanistic Sciences 18 (2014) 80-89.

[45] Daniela Gîfu, Mirela Teodorescu, International Letters of Social and Humanistic Sciences 18 (2014). 48-57.

[46] Florentin Smarandache, Ştefan Vlăduţescu (2014). Communication Neutrosophic Routes. Columbus, OH: Educational Publishing.

[47] Jason L. Powell, International Letters of Social and Humanistic Sciences 7 (2014) 22-30.

[48] Daniela Gîfu, Mirela Teodorescu, International Letters of Social and Humanistic Sciences 17 (2014) 119-127.

[49] Andrezj Borowski, International Letters of Social and Humanistic Sciences 2 (2014) 110-121.

[50] Ştefan Vlăduţescu, International Letters of Social and Humanistic Sciences 10(2) (2014) 100-106.

[51] Daniela Gîfu (2014). Humor in the Religious Discourse: between Paradoxism and Neutrosophy. Communication Neutrosophic Routes.

[52] Jason L. Powell, International Letters of Social and Humanistic Sciences 17(1) (2014) $1-60$.

[53] Ioan Constantin Dima, Mariana Man (2014). Information and Computer Engineering in neutrosophic managerial decision. Communication Neutrosophic Routes.

[54] Max G. Craig, Journal of Studies in Social Sciences 8(1) (2014).

[55] Ştefan Vlăduțescu, Journal of Sustainable Development Studies 6(1) (2014).

[56] A. Traistaru (2013). Consolidation of the green marketing profile in current austerity period. Jokull.

[57] Janusz Grabara, Vladimir Modrak, Ioan Constantin Dima, International Letters of Social and Humanistic Sciences 15 (2014) 148-156.

[58] Petre Bosun, Alina Tenescu, Ioan Constantin Dima, International Letters of Social and Humanistic Sciences 16 (2014). 75-85. 
[59] Ştefan Vlăduţescu, Mitteilungen Klosterneuburg 64(1) (2014).

[60] Jason L. Powell, International Letters of Social and Humanistic Sciences 16(2) (2014) 108-121.

[61] Janusz Grabara, Ion Cosmescu (2014). Use of computer engineering in company's commercial and transport logistics. Communication Neutrosophic Routes.

[62] Maria Nowicka-Scowron, Ioan Constantin Dima, Ştefan Vlăduţescu, International Journal of Management Sciences and Business Research 1(8) (2012) 27-35.

[63] Jason L. Powell, International Letters of Social and Humanistic Sciences 16(2) (2014) 132-14.

[64] Rajesh K. Yadav, Nishant Dabhade, International Letters of Social and Humanistic Sciences 4 (2013) 49-69.

[65] Uloma Charity Oguzor, International Letters of Social and Humanistic Sciences 4 (2014) 97-104.

[66] Okezie A. Ihugba, Alex Odii, A. C. Njoku, International Letters of Social and Humanistic Sciences 5 (2014) 21-34.

[67] Okezie A. Ihugba, Bankoli Bankong, N. C. Ebomuche, International Letters of Social and Humanistic Sciences 5 (2014) 92-113.

[68] Tomáš Hes, Alena Neradová, Karel Srnec, International Letters of Social and Humanistic Sciences 7 (2013) 55-75. 